\title{
EFFECT OF INSECTICIDES ON FUNGAL ENZYMES
}

\author{
RATNA SINGH, LEELA IYENGAR, AND A. V. S. PRABHAKARA RAO \\ Environmental Engineering Laboratory, Department of Civil Engineering, \\ Indian Institute of Technology, Kanpur, India
}

(Received February 14, 1977)

\begin{abstract}
Synthesis of alkaline phosphatase in Aspergillus flavus is markedly inhibited by chlorinated hydrocarbons whereas acid phosphatase and invertase are unaffected. Cellulase production and growth of Trichoderma viride are inhibited by DDT, Lindane, Endrin, and Heptachlor. Amylase formation by $A$. oryzae is significantly decreased in the presence of insecticides.
\end{abstract}

Pest control using chemical insecticides is necessary for the production of food and maintenance of health. It is equally important to protect, at the same time, other living organisms that keep the ecological balance in nature. Many pesticides are known to affect birds (1), fish (2), and other life, gaining entrance through food chain concentrations $(3,4)$.

Insecticides bring about their physiological reactions through their effect on specific biochemical events of the organism. Since all reactions of a cell are catalysed by enzymes, pesticides should affect the activity of enzymes. Several enzymes of diverse origin are inhibited by pesticides. ATP-ase, succinic dehydrogenase, and glutamate-pyruvate transaminase of insects are inhibited by chlorinated hydrocarbons (5-7). Studies on the effect of insecticides on microorganisms similarly have shown that several metabolic activities are inhibited in the presence of chlorinated hydrocarbons. It is reported that Chlordane interfered with the synthesis of an inducible enzyme, pyrocatechase in Aspergillus niger (8). Production of penicillin by Penicillium funiculosum was significantly decreased in the presence of Heptachlor (9). Growth of Nitrobactor agilis is inhibited by Chlordane, Heptachlor, Lindane, and DDT (10). Cyclodiene pesticides inhibited yeast growth by specifically interfering with oxidative metabolism (11). These observations show clearly that pesticides affect the microorganisms which in turn may result in interference in ecological cycle, as many of the organic compounds which find their way into soil are degraded by soil microbes to cycle them back into circulation. In order to obtain more information on the nature of interference by pesticides on fungal metabolism, experiments were conducted and results are presented here. 


\section{MATERIALS AND METHODS}

\section{Media and Culture Conditions}

Organism. Aspergillus flavus was obtained from the Botany Department, University of Lucknow. Trichoderma viride PRt strain 1059 and Aspergillus oryzae 634 were purchased from NCIM, Poona.

(a) Aspergillus flavus was grown on Czapek-Dox liquid medium containing sucrose, $30 \mathrm{~g} /$ liter, and $50 \mathrm{ml}$ of this medium was inoculated with spore suspension of $A$. flavus and incubated at $30^{\circ} \pm 1^{\circ}$. To study the effect of pesticides, required concentrations of pesticide in ethanol solution was added to the medium after sterilisation. After $48 \mathrm{hr}$ of growth, the fungal mycelium was repeatedly washed with distilled water, dried with a filter paper, and stored at $0-4^{\circ}$ until required.

(b) Trichoderma viride was grown on Czapek-Dox medium in which $50 \%$ sucrose was replaced by cellulose. The organism was grown in $50 \mathrm{ml}$ of the medium at $30^{\circ}$ for 15 days.

(c) A synthetic medium containing starch, $3 \mathrm{~g} ; \mathrm{NaNO}_{3}, 1 \mathrm{~g} ; \mathrm{KH}_{2} \mathrm{PO}_{4}, 0.1 \mathrm{~g}$; $\mathrm{MgSO}_{4}, 0.05 \mathrm{~g} ; \mathrm{KCl}, 0.05 \mathrm{~g}$; and $\mathrm{FeSO}_{4}, 0.001 \mathrm{~g}$ in $100 \mathrm{ml}$ distilled water was used to grow Aspergillus oryzae. After sterilization, $50 \mathrm{ml}$ of this medium in $250-\mathrm{ml}$ Erlenmeyer flask was inoculated with a heavy suspension of $A$. oryzae. The organism was grown for 7 days at $30^{\circ}$.

Preparation of enzyme extract and assay of enzymes. (a) Endoenzymes. All operations were done between $0^{\circ}$ and $4^{\circ}$. A. flavus mycelium ( $3 \mathrm{~g}$ ) was mascerated with an equal weight of sand (acid washed) for $10 \mathrm{~min}$ in a mortar with a pestle and extracted with $15 \mathrm{ml}$ of distilled water. The extract was filtered through a cheese cloth and centrifuged at $5,000 \times g$ for $10 \mathrm{~min}$ in a refrigerated centrifuge. Its supernatant was used as the crude enzyme extract.

(b) Assay of alkaline phosphatase: Assay mixture consisted of $30 \mu \mathrm{mol}$ ethanolamine- $\mathrm{HCl}$ buffer ( $\mathrm{pH} 9.5$ ), $30 \mu \mathrm{mol}$ glycerophosphate, $1.6 \mu \mathrm{mol} \mathrm{MgSO}_{4}$, and $0.3 \mathrm{ml}$ of enzyme extract in a total volume of $2.0 \mathrm{ml}$. Contents were incubated at $37^{\circ}$ for $30 \mathrm{~min}$. The reaction was stopped by adding $0.5 \mathrm{ml}$ trichloroacetic acid (TCA). The white precipitate formed was removed by centrifugation and inorganic phosphate was estimated colorimetrically by the method of WHARTON and MCCARTY (12). Specific activity of the enzyme was expressed as nmol of phosphate liberated $/ \mathrm{min} / \mathrm{mg}$ protein.

(c) Assay of acid phosphatase: The reaction mixture contained $30 \mu \mathrm{mol}$ acetate buffer ( $\mathrm{pH} 4.5$ ), $30 \mu \mathrm{mol} \beta$-glycerophosphate, $1.6 \mu \mathrm{mol} \mathrm{MgSO}_{4}$, and $0.3 \mathrm{ml}$ enzyme extract in a total volume of $2 \mathrm{ml}$. The enzyme was assayed by the method of WHARTON and McCARTY (12).

(d) Assay of invertase: Invertase activity was assayed by determining the reducing sugar formed from sucrose (13). Reaction mixture containing $100 \mu \mathrm{mol}$ acetate buffer ( $\mathrm{pH} 5.0$ ), $300 \mu \mathrm{mol}$ sucrose, and $0.5 \mathrm{ml}$ enzyme in a total volume of $3.0 \mathrm{ml}$ was incubated at $30^{\circ}$ for $10 \mathrm{~min}$. The reaction was stopped by adding 
$2 \mathrm{ml}$ of 3,5-dinitrosalicylate reagent. Reducing sugar formed was estimated. Specific activity of invertase was expressed as $\mu \mathrm{g}$ of reducing sugar formed $/ \mathrm{min} / \mathrm{mg}$ protein.

(e) For in vitro experiments, assay procedures for alkaline phosphatase, acid phosphatase, and invertase were similar to those given above, except that incubation of the enzyme extract with the pesticide was carried out for $10 \mathrm{~min}$ before adding the substrate.

(f) Cellulase: Trichoderma viride was grown as described earlier. Culture filtrate was centrifuged to remove the suspended particles and clear supernatant was used as cellulase extract. Enzyme assay was done viscometrically (14) as well as by determining the reducing sugar formed. A mixture of $3.5 \mathrm{ml}$ cellulose $(1.2 \%)$, $1.5 \mathrm{ml}$ acetate buffer $(\mathrm{pH} 5.5,0.1 \mathrm{M})$, and $1.5 \mathrm{ml}$ enzyme extract in a total volume of $8.0 \mathrm{ml}$ was taken in a viscometer and kept in a water bath at $30^{\circ}$. After regular intervals of $15 \mathrm{~min}$, the loss of viscosity was determined. The relative enzyme activity was calculated from the equation $\mathrm{REA}=1000 / t$ at $\mathrm{V}_{50}$, where $t$ at $\mathrm{V}_{50}$ is the time taken for $50 \%$ loss in viscosity (14). Reducing sugar was determined colorimetrically using 2,4-dinitrosalicylate reagent.

(g) Amylase: Aspergillus oryzae was grown in a medium containing starch for 7 days. Culture filtrate was separated from the mycelium, centrifuged to remove suspended particles, and was stored at $4^{\circ}$ until used. The reaction mixture for amylase assay consisted of $5 \mathrm{ml}$ buffered starch solution $(1 \%), 3 \mathrm{ml}$ acetate buffer $(\mathrm{pH} 4.6,0.1 \mathrm{M})$, and $1.0 \mathrm{ml} \mathrm{CaCl}{ }_{2}(0.05 \mathrm{M})$. After equilibrating the reaction mixture for $10 \mathrm{~min}$ at $40^{\circ}, 1 \mathrm{ml}$ enzyme extract was added. The reaction was stopped after $10 \mathrm{~min}$ by adding $2 \mathrm{ml}$ of $1 \mathrm{~N} \mathrm{HCl}$. Starch disappearance in an aliquot was determined by iodometry (15). Specific activity was expressed as $\mathrm{mg}$ starch hydrolysed/min/mg protein. Reducing sugar was also estimated.

Protein was determined by the method of Lowry et al. (16).

DDT ( $p, p^{\prime}$-dichlorodiphenyltrichloroethane), Lindane (isomer of benzene hexachloride), Endrin (1,2,3,4,10,10-hexachloro-6,7-epoxy-1,4,4a,5,6,7,8,8a-octahydro-1,4-endo-endo-5,8-dimethanonaphthalene), and Heptachlor (1,4,5,6,7,8,8heptachloro-3a,4,7,7a-tetrahydro-4,7-endo-methanoindene) were purchased from Bharat Pulverising Mills, India.

\section{RESULTS AND DISCUSSION}

Many metabolic activities of microorganisms are affected by chlorinated hydrocarbons $(8-10)$. Results presented here are on the effect of these insecticides on endo- and exo-cellular enzymes of fungi.

The effect of insecticides on alkaline phosphatase activity of $A$. flavus is shown in Table 1. DDT, Lindane, Endrin, and Heptachlor in the culture media reduced the synthesis of this enzyme. Percentage inhibition increased with increase in the concentration of pesticide in the medium. There does not seem to be any 
Table 1. Effect of pesticides on activity of alkaline phosphatase of A. flavus.

\begin{tabular}{|c|c|c|c|c|}
\hline \multirow{2}{*}{ Sl. No. } & \multicolumn{2}{|c|}{$\begin{array}{l}\text { Concentration } \\
\text { of pesticide } \\
(\mu \mathrm{g} / \mathrm{ml} \text { medium })\end{array}$} & \multirow{2}{*}{$\begin{array}{c}\begin{array}{c}\text { Specific activity } \\
\left(\text { nmol } \mathrm{P}_{\mathrm{i}} / \mathrm{min} / \mathrm{mg}\right. \\
\text { protein) }\end{array} \\
31.1\end{array}$} & \multirow{2}{*}{$\frac{\text { Activity }(\%)}{100.0}$} \\
\hline & Control & & & \\
\hline & Heptachlor & 10 & 20.6 & 66.23 \\
\hline & & 20 & 14.4 & 46.3 \\
\hline & & 30 & 8.08 & 25.7 \\
\hline \multirow[t]{4}{*}{2} & Control & & 50.0 & 100.0 \\
\hline & Lindane & 10 & 36.5 & 73.0 \\
\hline & & 20 & 29.5 & 59.0 \\
\hline & & 30 & 21.6 & 43.2 \\
\hline \multirow[t]{4}{*}{3} & Control & & 42.0 & 100.0 \\
\hline & Endrin & 10 & 30.0 & 71.4 \\
\hline & & 20 & 25.2 & 60.0 \\
\hline & & 30 & 16.8 & 40.0 \\
\hline \multirow[t]{4}{*}{4} & Control & & 37.0 & 100.0 \\
\hline & DDT & 10 & 30.1 & 81.4 \\
\hline & & 20 & 27.6 & 74.6 \\
\hline & & 30 & 20.1 & 54.3 \\
\hline
\end{tabular}

A. flavus was grown on Czapek-Dox medium. Pesticides were added to the medium as given in MATERIALS and METHODS. Alkaline phosphatase was assayed by determining inorganic phosphate liberated.

specificity towards pesticides as all the four pesticides affected the synthesis to the same degree.

Biochemical role of alkaline phosphatase is to hydrolyse organic phosphates to liberate inorganic phosphate, which can be utilized for phosphorylation reactions. Release of inorganic phosphate is also required for the maintenance of a steady pool of phosphate in cell environment. Presented results show that the synthesis of this enzyme is significantly decreased in the presence of chlorinated hydrocarbons. This may affect the energy metabolism of the cell. Earlier results have shown that, at concentrations used in the present experiment, Heptachlor significantly decreased the growth of A. flavus (9). Interestingly, occupational exposure of human beings to chlorinated hydrocarbons resulted in the increase of activities of alkaline phosphatase, fructose-1,6-diphosphate aldolase, and glutamatepyruvate transaminase in blood serum (17). With higher organisms, with their complex structure, it is difficult to determine the direct effect of pesticides as the increase in enzyme activity can be either due to the increased synthesis of the enzyme or an indirect effect of pesticides on some other organ which results in the increased enzyme activity in serum. In vitro experiments on the effect of chlorinated hydrocarbons on alkaline phosphatase from A. flavus (Table 3) showed that none of these insecticides had any effect on the activity indicating that the synthesis of this enzyme, not the activity, is affected by these chemicals.

Effect of pesticides on the synthesis of acid phosphatase is shown in Table 2. 
Table 2. Effect of pesticides on activity of acid phosphatase of A. flavus.

\begin{tabular}{|c|c|c|c|c|}
\hline S1. No. & $\begin{array}{r}\text { Concentra } \\
\text { of pestici } \\
(\mu \mathrm{g} / \mathrm{ml} \mathrm{med}\end{array}$ & $\begin{array}{l}\text { tion } \\
\text { de } \\
\text { ium) }\end{array}$ & $\begin{array}{c}\text { Specific activity } \\
\text { (nmol of } \mathbf{P}_{\mathrm{i}} / \mathrm{min} / \\
\text { mg protein) }\end{array}$ & Activity $(\%)$ \\
\hline \multirow[t]{4}{*}{1} & Control & & 47.1 & 100.0 \\
\hline & Heptachlor & 10 & 45.6 & 96.8 \\
\hline & & 20 & 43.7 & 92.8 \\
\hline & & 30 & 39.1 & 83.0 \\
\hline \multirow[t]{4}{*}{2} & Control & & 33.4 & 100.0 \\
\hline & Lindane & 10 & 33.4 & 100.0 \\
\hline & & 20 & 32.5 & 97.3 \\
\hline & & 30 & 31.8 & 95.2 \\
\hline \multirow[t]{4}{*}{3} & Control & & 23.0 & 100.0 \\
\hline & Endrine & 10 & 23.0 & 100.0 \\
\hline & & 20 & 22.5 & 95.7 \\
\hline & & 30 & 20.5 & 89.0 \\
\hline \multirow[t]{4}{*}{4} & Control & & 31.5 & 100.0 \\
\hline & DDT & 10 & 31.4 & 99.7 \\
\hline & & 20 & 31.7 & 100.6 \\
\hline & & 30 & 31.4 & 99.7 \\
\hline
\end{tabular}

A. Alavus was grown in the presence of required concentrations of pesticide. Assay of acid phosphatase was done as described in MATERIALS and METHODS.

Table 3. In vitro effect of pesticides on endo-enzymes of A. flavus.

\begin{tabular}{lccc}
\hline & $\begin{array}{c}\text { Alkaline phosphatase } \\
\text { activity }(\%)\end{array}$ & $\begin{array}{c}\text { Acid phosphatase } \\
\text { activity }(\%)\end{array}$ & $\begin{array}{c}\text { Invertase } \\
\text { activity }(\%)\end{array}$ \\
\hline Control & 100 & 100 & 100 \\
Heptachlor & 102 & 105 & 103 \\
DDT & 96 & 99 & 100 \\
Lindane & 96 & 103 & 100 \\
Endrin & 100 & 99 & 105 \\
\hline
\end{tabular}

Assay of alkaline phosphatase, acid phosphatase, and invertase was done as described in MATERIALS AND METHODS, except that pesticide $(30 \mathrm{~g})$ was preincubated with the enzyme for $10 \mathrm{~min}$ before adding the substrate.

None of the compounds had any effect on this enzyme. This is in contrast to the effect of insecticides on alkaline phosphatase. Recent studies have shown that, in $A$. oryzae, there are two distinct acid phosphatases which are localized at the surface structures such as cell wall and cytoplasmic membrane (18). Biochemical role of acid phosphatases may be different from that of alkaline phosphatase which is involved in energy metabolism.

Invertase activity of $A$. flavus in the presence of insecticides was determined. Results showed that DDT, Lindane, Endrin and Heptachlor did not affect the synthesis of this enzyme. Specific activities of invertase in control and in the 
presence of DDT, Lindane, Endrin, and Heptachlor were 66.6, 66.6, 60.0, 64.0, and 55.4, respectively. Neither acid phosphatase nor invertase was inhibited in vitro by insecticides.

Many fungi have the capacity to degrade otherwise non-degradable cellulose. Trichoderma viride is one such organism. Significant decrease in cellulase formation by $T$. viride was observed in the presence of insecticides (Table 4). Heptachlor was most inhibitory followed by Endrin, Lindane, and DDT. There was a gradual increase in percentage inhibition of cellulase formation as the concentration of pesticides was increased. There was a considerable change in the growth pattern of the fungus in the presence of chlorinated hydrocarbons, as the dry weight of fungus decreased considerably.

Table 4. Effect of pesticides on the production of cellulase by Trichoderma viride.

\begin{tabular}{|c|c|c|c|c|c|c|}
\hline \multirow{2}{*}{$\begin{array}{l}\text { Sl. } \\
\text { No. }\end{array}$} & \multirow{2}{*}{\multicolumn{2}{|c|}{$\begin{array}{l}\text { Concentration } \\
\text { of pesticide } \\
(\mu \mathrm{g} / \mathrm{ml} \text { medium })\end{array}$}} & \multirow{2}{*}{$\begin{array}{l}\text { Relative } \\
\text { enzyme } \\
\text { activity }\end{array}$} & \multicolumn{2}{|c|}{ Enzyme activity $(\%)$} & \multirow{2}{*}{$\begin{array}{l}\text { Weight of } \\
\text { mycelium } \\
\text { (g) }\end{array}$} \\
\hline & & & & $\begin{array}{l}\text { Viscosity } \\
\text { method }\end{array}$ & $\begin{array}{l}\text { DNS } \\
\text { method }\end{array}$ & \\
\hline \multirow[t]{4}{*}{1} & Control & & 31.0 & 100.0 & 100.0 & 1.4934 \\
\hline & Heptachlor & 10 & 22.9 & 74.1 & 70.0 & 0.9247 \\
\hline & & 20 & 18.8 & 56.1 & 51.1 & 0.9001 \\
\hline & & 30 & 14.0 & 45.1 & 45.0 & 0.8969 \\
\hline \multirow[t]{3}{*}{2} & Lindane & 10 & 26.0 & 83.0 & 81.0 & 1.2250 \\
\hline & & 20 & 21.6 & 65.1 & 66.3 & 1.0347 \\
\hline & & 30 & 18.0 & 58.0 & 61.0 & 0.9624 \\
\hline \multirow[t]{3}{*}{3} & Endrin & 10 & 22.7 & 73.2 & 75.0 & 1.2675 \\
\hline & & 20 & 20.0 & 64.0 & 64.0 & 0.9974 \\
\hline & & 30 & 16.6 & 54.0 & 54.0 & 0.9632 \\
\hline \multirow[t]{3}{*}{4} & DDT & 10 & 27.7 & 89.3 & 90.0 & 1.4212 \\
\hline & & 20 & 24.0 & 77.4 & 74.4 & 1.1948 \\
\hline & & 30 & 19.6 & 63.2 & 65.0 & 0.9830 \\
\hline
\end{tabular}

$T$. viride was grown on Czapek-Dox medium where $50 \%$ sucrose was replaced by cellulose. Cellulase activity was assayed by determining the loss of viscosity with time.

Cellulases produced by some soil fungi and microorganisms degrade cellulosic material to maintain soil fertility. The decrease in the production of cellulase of fungi in the presence of pesticides may affect the carbon recycling.

Amylase formation as affected by pesticides in A. oryzae is shown in Table 5. There was about $50 \%$ reduction in the formation of amylase in the presence of $30 \mu \mathrm{g}$ of pesticide/ml medium. DDT, Lindane, Endrin, and Heptachlor did not have antifungal activity at these concentrations as there was not much decrease in growth. Effect of antibiotics such as streptomycin, tetracycline, and grieseoflavin in amylase production was studied by AgARWAL and RAO (19). They found that there was a decrease in the production of amylase in the presence of antibiotics. Some of them acted as antifungals by decreasing the growth of fungi. Results 
Table 5. Effect of pesticides on the production of amylase by Aspergillus oryzae.

\begin{tabular}{|c|c|c|c|c|c|c|}
\hline \multirow{2}{*}{$\begin{array}{l}\text { Sl. } \\
\text { No. }\end{array}$} & \multirow{2}{*}{\multicolumn{2}{|c|}{$\begin{array}{l}\text { Concentration } \\
\text { of pesticide } \\
(\mu \mathrm{g} / \mathrm{ml} \text { medium })\end{array}$}} & \multirow{2}{*}{$\begin{array}{c}\text { Sugar } \\
\text { formed } \\
(\mu \mathrm{mol} / \mathrm{min} / \mathrm{mg} \mathrm{P})\end{array}$} & \multicolumn{2}{|c|}{ Enzyme activity $(\%)$} & \multirow{2}{*}{$\begin{array}{l}\text { Dry weight } \\
\text { of mycelium } \\
\text { (g) }\end{array}$} \\
\hline & & & & $\begin{array}{l}\text { Reducing } \\
\text { sugar }\end{array}$ & $\begin{array}{l}\text { Starch } \\
\text { disappearance }\end{array}$ & \\
\hline \multirow[t]{4}{*}{1} & Control & & 1.9 & 100.0 & 100.0 & 2.0156 \\
\hline & Heptachlor & 10 & 1.04 & 54.6 & 52.0 & 1.9201 \\
\hline & & 20 & 0.87 & 45.2 & 45.0 & 1.7399 \\
\hline & & 30 & 0.77 & 40.5 & 38.0 & 1.6012 \\
\hline \multirow[t]{3}{*}{2} & Lindane & 10 & 1.3 & 68.0 & 68.1 & 1.9798 \\
\hline & & 20 & 1.1 & 57.0 & 54.5 & 1.8063 \\
\hline & & 30 & 0.86 & 45.2 & 42.1 & 1.6329 \\
\hline \multirow[t]{3}{*}{3} & Endrin & 10 & 1.4 & 73.0 & 77.1 & 2.0000 \\
\hline & & 20 & 1.02 & 52.0 & 56.7 & 1.8712 \\
\hline & & 30 & 0.88 & 46.0 & 43.6 & 1.7433 \\
\hline \multirow[t]{3}{*}{4} & DDT & 10 & 1.8 & 89.4 & 95.0 & 2.1002 \\
\hline & & 20 & 1.5 & 79.9 & 81.8 & 1.9987 \\
\hline & & 30 & 0.94 & 49.4 & 52.2 & 1.8054 \\
\hline
\end{tabular}

Aspergillus oryzae was grown on a synthetic medium in which starch was the carbon source. Amylase activity was determined both by estimating the starch hydrolysed as well as the reducing sugar formed.

of the present studies show that pesticides also have similar effect on fungi.

One of the authors (R.S.) is grateful for the financial support from Council of Scientific and Industrial Research (CSIR), India, during the progress of this work.

\section{REFERENCES}

1) J. J. Hickey and D. W. Anderson, Science, 162, 271 (1968).

2) J. K. MaceK, C. Hutchinson, and O. B. Cope, Bull. Environ. Contam. Toxicol., 3, 174 (1969).

3) U. B. Dawn and D. Wagman, J. Am. Water Works Assoc., 61, 36 (1969).

4) W. W. Gregory, J. K. Reid, and L. E. Priesten, Jr., J. Protozool., 16, 64 (1969).

5) Y. C. Chu and L. K. CutкomP, J. Econ. Entomol., 64, 559 (1971).

6) V. P. Kubaichuk, Nauk. Pr. Ukr. Akad. Silskogspod Nauk, 9, 57 (1968).

7) L. Iyengar, C. Venkobachar, and A. V. S. P. RaO, Environ. Physiol. Biochem., 2, 50 (1972).

8) L. IYeNGAR and A. V. S. P. RAO, Ind. J. Microbiol., 14, 201 (1974).

9) R. Singh, L. Iyengar, and A. V. S. P. RaO, Indian J. Exp. Biol., 14, 466 (1976).

10) C. L. Winely and C. L. S. Clemente, Appl. Microbiol., 19, 214 (1970).

11 ) B. D. Nelson and C. Williams, J. Agric. Food Chem., 19, 339 (1971).

12) D. C. Wharton and E. McCarTy, In Experiments and Methods in Biochemistry, Macmillan Press, New York (1972), p. 238.

13) D. T. Plummer, In An Introduction to Practical Biochemistry, McGraw-Hill Book Company, London, P. 119 (1971).

14) C. Mehta and S. C. Agarwal, Hind. Antibiot. Bull., 15, 86 (1973).

15) B. G. Manning and L. L. CAMPBell, J. Biol. Chem., 236, 2952 (1961).

16) D. H. Lowry, N. J. Rosebrough, F. A. Lewis, and R. J. Randall, J. Biol. Chem., 193, 265 
(1951).

17) M. Bogusz, Clin. Chim. Acta, 19, 367 (1968).

18) N. Wakae, Y. Sakurai, H. Shiota, and I. Tanimura, J. Gen. Appl. Microbiol., 21, 233 (1975).

19) S. C. Agarwal, and D. P. Rao, Hind. Antibiot. Bull., 16, 206 (1974). 